\title{
The use of "kaun" (Local Potash) as a mineral source in the diet of West African Dwarf sheep
}

\author{
Adeleye, A. Mojisola, A.B.J. Aina and I.F. Adu \\ Department of Animal Production and Health, University of Agriculture, Aheokuta, Nigeria
}

\begin{abstract}
The study was conducted for 48 days to assess the use of kaun as a source of mineral for West African Dwarf sheep. The study was in two parts. Experiment 1 involved the use of milled kaun mixed with formulated concentrate consisting of wheat offal (50\%), palm kemel cake (25\%) and dried brewer's grains (25\%). Experiment II was the use of dissolved kaun administered to the' animals in form of drenching. Each group of animals in experiment I was allocated to experimental diet containing milled kaun $(0.00,0.14,0.28,0.45$ and $0.56 \mathrm{~g} / \mathrm{kg}$ body weight/ram day) and to kaun solution $(0,2,4,6$ and $8 \mathrm{~g} / 10 \mathrm{ml}$ of water/ram/dav) in experiment 11 . In Experiment $\mathrm{I}$, significant $(P<0.05)$ effects of the diets were observed on average daily gain, dry matter intake and water consumption. The rams on D3 significantly $(P<0.05)$ performed better in daily gain, dry matter intake and feed efficiency than those on other dietary treatments. Water consumption increased with increasing level of kaun in the diets. Animals on D5 had the highest water consumption. No significant $(P>0.05)$ effects of the diets were observed on faecal and urinary mineral outputs of the rams fed kaun supplemented diet. The concentration of these minerals was higher at the end of the experiment than at the beginning thereby giving positive balance. Significant $(P<0.05)$ negative mineral balance was noticed between serum mineral before and after the experiment. This could suggest that mineral utilization was encouraged by kaun inclusion in the concentrate feed. In Experiment II, there were significant $(P<0.05)$ effects of the test diets on werage daily gain, drv matter intake and water consumption. Diet 4 (6g/loml of water/ram/day) and 05 ( $8 \mathrm{~g} / 1 \mathrm{~lm} / \mathrm{m}$ of water/ram'doy) performed better with an average daily gain of $100 \mathrm{~g} / \mathrm{d}$ and $92.9 \mathrm{~g}$ d; drv matter intake, $70 \mathrm{~g} W^{0.75} \mathrm{~kg}$ and $66 \mathrm{~g} / \mathrm{W}^{0.75} \mathrm{~kg}$; feed efficiency 0.700 and 0.710 , respectively. Water consumption also increased with increase in the concentration of kanu solution but water consumption in treatment groups was lower than in the control $(0.10 \mathrm{~L} / \mathrm{kg}$ body weight $)$. The results of this study suggest that $0.28 \mathrm{~g} \mathrm{kaun} \mathrm{kg}$ body weight/ram/d) promoted better performance in experiment 1 while $6 \mathrm{~g} \mathrm{kaun} / \mathrm{lOml}$ of water, or $8 \mathrm{~g}$ kaun $10 \mathrm{ml}$ of water/ram/d promoted better performance in experiment II. These levels of kaun as a source of mineral in sheep production are therefore recommended for optimum performance.
\end{abstract}

Keywords: Kaun, serum mineral, daily gain. West African dwarf shecp

\section{Introduction}

The advantage of mineral supplementation in enhancing the performance of grazing animals has been established (lvery, et al., 1986; Van Hourter and Leng, 1991). However. in the traditional ruminant production systems, mineral premix is not normally included in the diets of the animals. This could be due to ignorance on the part of livestock owners who may not be aware of the importance of such mineral source. 
or unavallability and highs cost of mineral premix (Okagbare and Akinsoyinu, 1998). Grazing livestock from the tropical countries often depend almost exclusively on forages, which are low in minerals for their requirements (French, 1957; McDowell et al., 1984). The problem is further compounded by the everincreasing demographic growth which, over the years has reduced the available land for extensive grazing (Aina, 2002). Consequently, the need to search for a cheaper and readily available mineral sources is imperative. Mineral premix for ruminant ( $40 \%$ egg shell, $40 \%$ bone meal and $20 \%$ common salt; Payne, 1990). Is scarce and expensive and require expertise in compounding it.

However, käun, popularly called 'local potash' and also known as 'Trona' in the geological sector (Gbodi and Ikwuegbu, 1982, RMRDC, 1996) is a common household item and readily available in open markets in all rural communities in Nigeria. $\mathrm{OH}$ is traditionally added to vegetable as a tenderizer and enhancer of green colouration. It is also used to energize horse for effective transportation of goods over a considerable distance and used locally by rearers to fatten up rams toward festive period (Gbodi and Ikwuegbu, 1982). Chemical analysis of koun has shown that it is a repository of various essential mineral elements required by grazing animals (Ranjhan, 1980; Zogara et al., 1988; Idowu, 1994). Kaun unlike mineral premix, does not require expertise in preparation before foeding it to animals. It could be fed directly to ruminants without milling or part of concentrate. Koun is a dried lake salt, largely hydrated sodium bicarbonate (Davidson et al., 1974), occasionally encountered as a saline lake deposit or evaporation product, and as an efflorescent on arid soil. It is a product of the salt industry in many parts of Nigeria and North Africa (RMRDC, 1996). This study was conducted to assess the nutritional implications of Kaun on the performance characteristics of the West African dwarf sheep.

\section{Materials and Methods}

Two experiments were conducted. The first experiment involved mixing milled Kaun with concentrate supplement at 5 levels of inclusion $(0.0, \quad 0.14, \quad 0.28, \quad 0.45, \quad 0.56 \mathrm{~g} / \mathrm{kg} /$ body weight/ram/day). The second experiment involved dissolving Kaun in water at 5 levels of concentration $\quad(0,2,4,6,8 \mathrm{~g} / 10 \mathrm{ml}$ of water/ram/day) and assigning the different concentrations to drench the animals in different groups.

\section{Experiment Site}

The study was carried out in the Small Ruminant Unit of the Teaching and Research Farm, University of Agriculture $\left(7^{\circ} 15^{\prime} \mathrm{N}\right.$ $3^{\circ} 25^{\prime} \mathrm{E}$ ) between May and October, 2001 which coincided with period of wet season.

\section{Experiment I- Experimental animal and management}

Twenty growing West African Dwarf rams, weighing between 13 and $15 \mathrm{~kg}$ were used for the experiment. The rams were purchased from the neighbouring villages. The rams were administered Petits pestes ruminants, braodspectrum antibiotics, dewormed with Barminth II and dipped in Asuntol powder solution $^{\mathrm{R}}$ to eliminate possible ectoparasites by Vetenarian. Clout ${ }^{R}$ was applied at 4 weeks intervals along the spine of the animals to curb mange infection. At the end of 3 weeks adaption period, the animals were grouped into 5 dietary treatments of $\mathbf{4}$ rams per treatment balanced for body weight. The rams were maintained on Guinea grass (Panicum moximum) concentrate supplement and water was ad-libitum for the 3 weeks of adjustment period in order to estimate their feed intake and water consumption before the commencement of the experiment.

\section{Dietary treatment}

The Kaun was milled into fine (about 0.2 to $0.02 \mathrm{~mm}$ particle size) form while the concentrate supplement composed of palm kernel cake $(25 \%)$, wheat offal $(50 \%)$ and dry brewer's grains ( $25 \%)$ giving the calculated crude protein $(18.8 \%)$, crude fibre $(13.8 \%)$ and 


\section{Kann inclasion in the diet of WAD sheep}

metabolizable energy $(10.60 \mathrm{MJ} / \mathrm{kg})$. Each of the 5 groups was randomly assigned to a level of Kaun $(0,2,4,6,8 \mathrm{~g} / \mathrm{ram} / \mathrm{day})$. In order to ensure total consumption of the daily allotted Kaun, about $50 \mathrm{~g}$ of the concentrate supplement (to serve as carrier of the Kaun) was mixed with the Kaun. The mixture was first supplied to each group. After total consumption of the mixture, the remaining concentrate was then supplied to make $0.40 \mathrm{~kg} / \mathrm{ram} / \mathrm{d}$ while $P$.maximum and water was offered ad-libitum once daily between 0080 and $0090 \mathrm{hr}$. The animals were fed the experimental diet for 12 weeks.

\section{Data collection}

The body weight of each animal was taken before the experiment and fortnightly after 1416 hours withdrawal of feed. Feed and grass refused were measured and recorded every morning to determine the feed intake. Water intake was estimated by subtracting the left-over from supply. Blood samples were collected via the jugular vein puncture (Frandson, 1986) prior to the commencement (zero week) and at the end of the experiment (week 12) and serum was harvested (Heath and Olusanya, 1988) for mineral estimation. The faecal and uninary outputs from each animal were collected for 7 days in metabolic cages following the standard procedure (Aina and Akinsoyinu, 1996). About $10 \%$ of total faecal and urinary output were used for analysis. The faecal samples collected was oven-dried at $80^{\circ} \mathrm{C}$ to constant weight. The urinary was collected in a sample bottle with plastic covers, rinsed with $20 \%$ dilute sulphuric acid and then stored in a deep freezer at $-20^{\circ} \mathrm{C}$ for subsequent analysis. The average temperature and relative humidity during this study were $34.7^{\circ} \mathrm{C}$ and $82 \%$ respectively.

\section{Chemical analysis}

Two grams (2g) oven-dried and milled faecal, $10 \mathrm{ml}$ urinary and $2 \mathrm{ml}$ serum samples were separately digested in separate $125 \mathrm{ml}$ Erlenmayer Flasks which have been previously washed with dilute $\mathrm{H}_{2} \mathrm{SO}_{4}$ and distilled water. Added to each sample were $4 \mathrm{ml}$ of perchloric acid, $25 \mathrm{ml}$ concentrated $\mathrm{HNO}_{3}$ and $2 \mathrm{ml}$ concentrated $\mathrm{H}_{2} \mathrm{SO}_{4}$. The content of each flask was mixed and gently heated at low-to-medium heat on a hot plate under perchloric acid fumehood. Heating was continued until dense white fumes appeared. The mixture is finally strongly heated (medium to high heat) for half a minute and then allowed to cool. Distilled water (50ml) was added and boiled for $1 / 2$ minute on the same mate of medium heat. The solution was then cooled and filtered (with Whatman No. 42 filter paper) completely with a wash bottle into a 100ml Pyrex volumetric flask; then made up to mark with distilled water.

The $\mathrm{Na}, \mathrm{K}$, and $\mathrm{Ca}$ contents of each digested sample were estimated by Flame Photometry method while the $P$ concentration was estimated using Vanadomolybdate Coloric method (IITA, 1978) while the concentration of $\mathrm{Fe}$ and $\mathrm{Mg}$ were determined using Perking Elmer Atomic Absorption Spectrophotometer (AAS).

\section{Experiment II - Management of the experimental animals}

The $20 \mathrm{rams}$ that were used in Experiment I weighing between 16 and $17.5 \mathrm{~kg}$ were allowed to rest for three weeks before the commencement of Experiment II. During the resting period, they were released to graze on paddock, supplemented with concentrate diet and water. At the end of the 3 weeks they were randomly divided into 5 dietary treatment groups of 4 rams per group balanced for body weight.

\section{Preparation of experimental diet}

Kaun was dissolved in water at five levels of concentration $\quad(0,2,4,6,8 \mathrm{~g} / 10 \mathrm{ml}$ of water/ram/day). The concentrate offered was as presented in Experiment I.

\section{Dietary treatment}

Each group was randomly assigned to Kaun solution. The solution was administered by drenching it directly into the mouth of each ram using $10 \mathrm{ml}$ syringe by $0080 \mathrm{hr}$. the concentrate supplement was offered at $4 \%$ body weight. 
Grass and water were supplied ad-libitum while the treatment lasted for 12 weeks.

\section{Data collection}

The animals were weighed fortnightly before morning feed. The feed rejected and the leftover water were weighed and measured respectively on daily basis to estimate the dry matter and water intakes. Blood samples were collected via the jugular vein puncture (Frandson, 1986) prior to the beginning and at the end of the experiment. Sera were harvested to estimate serum mineral concentration as described before.

\section{Statistical analysis}

The data colleted (Experiment I and II) were subjected to analysis of variance (Wahua, 1991). Differences among treatment means were significant were separated using Duncan (1955) Multiple Range Test.

\section{Results and Discussion}

Table 1 shows the proximate component of Kaun as determined (\%). The values contained in table are the average of 3 samples from the same source. It showed the potential of Katm as mineral source (Idowu, 1994) in the diet of ruminants. Kaun contains many of the minerals required by sheep as it is fairly high in $\mathrm{P}(32.5 \pm$ $0.03 \%), \mathrm{Na}(20.19 \pm 0.30 \%), \mathrm{Cl}^{-},(16.25 \pm$ $0.11 \mathrm{mg} / \mathrm{l}), \mathrm{HCO}_{3-}(13.55 \pm 2.10 \mathrm{mg} / \mathrm{l})$, and $\mathrm{CO}_{3}$ $(12.80 \pm 0.02 \mathrm{mg} / \mathrm{l})$. It appears that the name local potash does not reflect the actual proportion of $\mathrm{K}$ present in Kaun as observed (Gbodi and Ikwuegbu, 1982; Idowh, 1994). It is fairly low in $\mathrm{Mg}(0.63 \pm 0.03 \%)$, Fe $(0.89 \pm$ $0.01 \%), \mathrm{Cu}(0.73 \pm 0.11 \%)$ and $\mathrm{Zn}(0.67 \pm$ $0.30 \%$ ). NRC (1988) stated different dietary mineral requirements for mature rams to be $\mathrm{Ca}$ $(0.20 \pm 0.82 \%), \mathrm{P}(0.16 \pm 0.38 \%), \mathrm{Na}(0.09 \pm$ $0.18 \%), \mathrm{Mg}(0.12+0.18 \%), \mathrm{K}(0.50+0.80 \%)$ and $\mathrm{Fe}(30-50 \% \mathrm{mg} / \mathrm{kg}), \mathrm{Cu}(7-11 \mathrm{mg} / \mathrm{kg})$ and $\mathrm{Zn}(20-33 \mathrm{mg} / \mathrm{kg})$. This suggests that inclusion of Kaun in the diet of sheep may meet the requirements for some of the minerals of sheep (Ranjhan, 1980). It appears that the inclusion of Kaun in the concentrate supplement of sheep could replace to a large extent the commercial ruminant mineral premix. However, the results of the chemical analysis. (Table 1) differ from that given by Idowu (1994). The reason for the variation could be attributed to the source of sample collection (RMRDC, 1996).

Table 1: Chemical composition of Kaun as determined (\%)

\begin{tabular}{ll}
\hline Components & Mean \pm SEM \\
\hline Moisture content & $7.96 \pm 2.01$ \\
Dry matter & $92.04 \pm 3.63$ \\
Calcium $(\mathrm{Ca})$ & $3.47 \pm 0.40$ \\
Phosphorus $(\mathrm{P})$ & $32.51 \pm 0.03$ \\
Sodium $(\mathrm{Na})$ & $20.19 \pm 0.03$ \\
Potassium $(\mathrm{K})$ & $6.08 \pm 0.10$ \\
Magnesium $(\mathrm{Mg})$ & $0.63 \pm 0.03$ \\
Iron $(\mathrm{Fe})$ & $0.89 \pm 0.01$ \\
Copper $(\mathrm{Cu})$ & $0.73 \pm 0.11$ \\
Zinc $(\mathrm{Zn})$ & $0.67 \pm 0.30$ \\
Chloride $(\mathrm{Cl})(\mathrm{mg} / \mathrm{l})$ & $16.25 \pm 0.11$ \\
Carbonate $\left(\mathrm{C} 0_{3}\right)(\mathrm{mg} / \mathrm{l})$ & $12.80 \pm 0.02$ \\
Hydrogen carbonate $\left(\mathrm{HCO}_{3}\right)(\mathrm{mg} / \mathrm{l})$ & $13.55 \pm 2.01$ \\
\hline \hline
\end{tabular}

Table 2 indicates the average performanoe of the rams drenched with Kaun solution. The average daily body weight gain in the drenched groups increased significantly $(\mathrm{P}<0.05)$ than animals on control while water intake was significantly $(\mathrm{P}<0.05)$ higher in animals on control than those 
in the drenched. The rams on D4 had the highest daily body weight gain $(100 \mathrm{~g} / \mathrm{d})$, followed by those on D2 $(97.1 \mathrm{~g} / \mathrm{d})$, D5 $(92.9 \mathrm{~g} / \mathrm{d})$, D3 $(91.4 \mathrm{~g} / \mathrm{d})$ respectively, while the control group had the least daily body weight gain $(57.1 \mathrm{~g} / \mathrm{d})$, although this is the higher in Experiment I $(28.6 \mathrm{~g} / \mathrm{d})$ and the poorest feed efficiency (1.053). It appeared that the control group had the poorest performance in terms of daily gain and feed efficiency which might connote important economic indice in animal production. It could be inferred that when Kaun solution is supplied in form of drenching to sheep, an encouraging performance is obtained (Aina and Abegunde, 2000). Water intake of the rams drenched with Kaun solution was significantly lower $(\mathrm{P}<0.05)$ than those in the control group (Table 2).

Table 2: Average performance of the rams drenched with koun solution (Experiment II)

\begin{tabular}{lllllll} 
Parameters & $\mathrm{D} 1$ & $\mathrm{D} 2$ & $\mathrm{D} 3$ & $\mathrm{D} 4$ & $\mathrm{D} 5$ & $\mathrm{SEM}$ \\
\hline $\begin{array}{l}\text { Average daily gain(g/d) } \\
\begin{array}{l}\text { Water intake(kg body } \\
\text { weight) }\end{array}\end{array}$ & 57.1 & 97.1 & 91.4 & 100.0 & 92.9 & 13.13 \\
$\begin{array}{l}\text { Dry matter } \\
\text { intake }\left(\mathrm{g} / \mathrm{W}^{0.75} \mathrm{~kg}\right)\end{array}$ & 0.100 & 0.056 & 0.058 & 0.063 & 0.057 & 0.067 \\
Feed efficiency & 60.00 & 70.00 & 65.00 & 70.00 & 66.00 & 0.03 \\
& 1.053 & $\mathbf{0 . 7 2 2}$ & $\mathbf{0 . 7 1 4}$ & 0.700 & 0.710 & 0.713 \\
\hline
\end{tabular}

The ratio of dry matter intake to water consumption in the drenched groups was fairly constant (1.11 to 1.25$)$. this ratio was close to the observation (Akinsoyinu, 1985) who reported that male West African dwarf sheep and goats need approximately $1.1 \mathrm{lkg}$ total water intake/kg dry matter for maintenance with ambient temperature between 27 and $29^{\circ} \mathrm{C}$ and relative humidity of 57 to $82 \%$.

Table 3 contains the performance of the rams on the Kaun-based diet. There was an increasing daily body weight gain and water consumption as the level of Kaun increased in the diet., daily gain was optimal in D3 $(74.3 \mathrm{~g} / \mathrm{d})$ and then declined $(35.7 \mathrm{~g} / \mathrm{d})$ as the level increased to D5.
The maximum water consumption $(0.052 \mathrm{~L} / \mathrm{kg}$ body weight) was probably induced by the diet containing the highest level of Kaun $(0.56 \mathrm{~g} / \mathrm{kg}$ body weight). The feed efficiency ippeared higher in the Kaun treated rams than the control with a better feed efficency depicted in D3 (0.662) while the least feed efficiency $(1.724)$ was noticed in the animals on the control diet. In general, the rams fed D3 exhibited significantly $(P<0.05)$ higher growth rate $(74.3 \mathrm{~g} / \mathrm{d})$, least dry matter intake $\left(49 \mathrm{~g} / \mathrm{W}^{0.75} \mathrm{~kg}\right)$ and better feed efficiency $(0.662)$ than the rams on the other treatments. There was no significant difference $(\mathrm{P}>0.05)$ between the performance of the rams fed D2 and those fed D3 in growth rate, dry matter intake and feed efficiency (Table 3).

Table 3: Average performance of West African Dwarf ram fed kaun supplemented diets

\begin{tabular}{lllllll} 
Parameters & $\mathrm{D} 1$ & $\mathrm{D} 2$ & $\mathrm{D} 3$ & $\mathrm{D} 4$ & $\mathrm{D} 5$ & $\mathrm{SEM}$ \\
\hline $\begin{array}{l}\text { Average daily gain(g/d) } \\
\text { Water intake(lkg body }\end{array}$ & 28.6 & 71.4 & 74.3 & 52.9 & 35.7 & 11.37 \\
$\begin{array}{l}\text { weight) } \\
\begin{array}{l}\text { Dry matter } \\
\text { intake (g/W }\end{array}\end{array}$ & 0.044 & 0.045 & 0.046 & 0.050 & 0.052 & 0.003 \\
Feed efficiency & 50.0 & 51.0 & 49.0 & 64.0 & 57.0 & 3.43 \\
\hline
\end{tabular}




\section{Adeleze, Ainn and Adu}

The animals on the control diet consistently performed poorer (28.6g/d) than those on Kaunbase diet in daily weight gain, water intake (0.0441/kg body weight) and feed efficiency (1.724). This observation supports submission (Ivery, et al., 1986; Van Hourter and Leng, 1991 and Lufadeju and Lamidi, 1993) that mineral supplementation enhanced better performances in the treated animals than the control.

The balance between the initial and final frecal mineral output are contained in Table 4 . the table shows that $\mathrm{Na}, \mathrm{K}, \mathrm{Ca}, \mathrm{P}, \mathrm{Mg}$ and $\mathrm{Fe}$ are in positive balance. However, the balance was significantly $(P<0.05)$ higher in the control group (zero Kaun inclusion) than in the Kauntreated groups. The reason for this observation was not understood. However, one could suggest that the Koun-based diets encouraged more mineral utilization in the treated groups than the control, or that Kaun may contain some un-identified growth factors which probably promoted mineral utilization.

Table 4: Faecal mineral balance of the rams fed kaun supplemented diets before and after the experiment

\begin{tabular}{|c|c|c|c|c|c|c|}
\hline Minérais (mg/kg) & D1 & D2 & D3 & D4 & Ds & SEM \\
\hline $\mathrm{Na}$ & 12.70 & 7.40 & 5.93 & 10.10 & 6.73 & 5.01 \\
\hline K & 17.50 & 11.27 & 8.57 & 14.33 & 12.80 & 3.03 \\
\hline $\mathrm{Ca}$ & 64.00 & 39.13 & 30.97 & 43.95 & 44.20 & 7.10 \\
\hline $\mathbf{P}$ & 470.20 & 318.50 & 229.67 & 367.80 & 325.17 & 12.13 \\
\hline Mg & 65.00 & 40.00 & 15.00 & 48.33 & 38.33 & 3.11 \\
\hline $\mathrm{Fe}$ & 89.17 & 54.67 & 33.33 & 59.63 & 48.33 & 6.17 \\
\hline
\end{tabular}

Table 5 shows the balance between the initial and final urinary mineral outputs of the experimental animals. The balance between the control and Kaun-treated groups did not follow any regular trend as in faecal output. However, they were all in positive balance except $\mathrm{Mg}$ balance in the control which was negative ($0.77 \mathrm{mg} / 100 \mathrm{ml}$ ). The $\mathrm{Mg}$ balance had the least value of all the minerals. This could be an indcation of higher utilization by the animals than what obtained for the other minerals. The utilization of mineral is dependent upon many factors including level of the element ingested, age of the animal, $\mathrm{pH}$ of the intestinal contents, state of the animal with respect to deficiency or adequacy of the element and the presence of other antagonistic minerals or nutrient (Fontenot et al., 1960, Hafez and Dyer, 1969, Fontenoit, Webb and Wise, 1973; Kemp, 1983). The positive balance further suggested that the inclusion of Kaun in the diet increased the urinary and faecal ontputs of the minerals. The results support the record of Bondi (1987), Church and Pond (1988) and Aina (1992) who observed that mineral absorbed in excess of body's requirement are exxreted mainly through faecal and urine but the major route of excretion is through freces. 
Table 5: Urinary mineral balance of rams fed kaun supplemented diets before and after the experiment

\begin{tabular}{lllllll}
\hline Minerals $(\mathrm{mg} / 100 \mathrm{ml})$ & D1 & D2 & D3 & D4 & D5 & SEM \\
\hline $\mathrm{Na}$ & 21.48 & 21.96 & 13.37 & 15.30 & 13.04 & 4.06 \\
$\mathrm{~K}$ & 31.05 & 30.90 & 39.63 & 10.20 & 11.40 & 5.10 \\
$\mathrm{Ca}$ & 102.13 & 124.20 & 87.43 & 89.10 & 61.03 & 21.66 \\
$\mathrm{P}$ & 86.72 & 80.53 & 69.04 & 34.51 & 41.09 & 11.33 \\
$\mathrm{Mg}$ & -0.77 & 0.13 & 0.10 & 0.90 & 0.60 & 0.07 \\
$\mathrm{Fe}$ & 1.33 & 1.44 & 0.80 & 0.94 & 0.83 & 0.33 \\
\hline \hline
\end{tabular}

In Table 6, almost all the animals exhibited negative serum mineral concentration except $\mathrm{Na}$ indicating higher pre-experimental mineral concentration in the serum of each animal than post-experimental one. This could suggest utilization of the minerals for physiological activities including osteogenesis and osmotic phenomena since the animals were still in the growing stage. Other likely reasons for the negative serum mineral balance include breed, age, climatic condition and/or the composition of the experimental diet (Bondi, 1987, Church and Pond, 1988). However, the rams treated with D3 consistently remained in the positive mineral balance except in Fe. This could mean that the optimum level of inclusion for maximum performance is contained in D3.

Table 6: Serum mineral balance of the rams fed kaun supplemented diets, before and after the experiment

\begin{tabular}{lllllll}
\hline Minerals (mg/100ml) & D1 & D2 & D3 & D4 & D5 & SEM \\
\hline $\mathrm{Na}$ & 14.22 & 17.23 & 37.50 & 2.72 & 17.03 & 7.11 \\
$\mathrm{~K}$ & -8.88 & -2.82 & 0.25 & -8.36 & -10.00 & -2.66 \\
$\mathrm{Ca}$ & -20.70 & -37.70 & 12.98 & -49.17 & -19.77 & -13.13 \\
$\mathrm{P}$ & -1.97 & -1.63 & 7.32 & -2.48 & -1.91 & -1.97 \\
$\mathrm{Mg}$ & -13.17 & -40.30 & 16.00 & -30.83 & -12.50 & -5.66 \\
$\mathrm{Fe}$ & -60.87 & -76.16 & -42.00 & -84.57 & -54.91 & -20.33 \\
\hline
\end{tabular}

Table 7 contains the packed cell volume (PCV), red blood cells (RBC), and white blood cells (WBC) of the rams prior to the commencement of the experiment. This was to ascertain the health status of the rams before the experiment. The values were in agreement with the record of
Schalm et al., (1975) and Heath and Olusanya (1988) for healthy sheep. This suggests that the rams were in good health condition as at the start of the experiment. Thus, any responses obtained could be attributed to treatment effects.

Table 7: Haematological parameters of the experimental animals before the commencement of the experiment

\begin{tabular}{lll}
\hline Parameters & Range & Mean \pm SEM \\
\hline Packed cell volume (PCV\%) & $25.00-31.00$ & $27.33 \pm 3.07$ \\
Red Blood Cells (RBC) $\left(\mathrm{mm} \times 10^{6}\right)$ & $12.33-13.73$ & $12.53 \pm 2.01$ \\
White Blood Celis (WBC) $\left(\mathrm{mm} \times 10^{3}\right)$ & $8.35-10.6$ & $9.15 \pm 1.96$ \\
\hline
\end{tabular}


The results of the two experiments indicated that the inclusion of Kaun in the diet of sheep either mixed with concentrate diet or as drench solution would encourage better performance by the animals. The serum mineral concentration in all the treatment groups including the control was higher before than after the experiment, thus giving significant $(\mathrm{P}<0.01)$ negative balances in all mineral considered except $\mathrm{Na}$. The reason for significant negative serum mineral balances could not be understood. However, it could be suggested that the animals utilized much of the serum minerals for some physiological developments such as osteogenesis of other tissue formation and osmotic activities. Mahan (1990) observed that mineral requirements in ruminants increases with age and physiological status of the animals. However, the negative balances noticed in this study did not reflect in the weight gain of the animals as Kaun-treated groups (dietary or drenched) significantly $(\mathrm{P}<0.05)$ gained more weight than the control. This suggest that administering Kaun to WAD rams either in the diet or by drenching as a source of mineral salts has beneficial effects on the animals. The better performance of the rams on Kaun solution than those on mixed diet suggests that the milled Kaun would have to undergo longer digestive processes before it could be utilized while the drenched ones undergo a shorter period of digestion before utilization. It is therefore recommended that up to $4 \mathrm{~g}$ of $\mathrm{Kaun} / \mathrm{ram} / \mathrm{day}$ $(0.28 \mathrm{~g} / \mathrm{kg}$ body weight/day) in the diet or $8 \mathrm{~g} / 10 \mathrm{ml}$ of water/ram/day) by drenching may be administered.

\section{Acknowledgement}

We acknowledge the financial assistance by the Research and Development Centre (RESDEC) of the University of Agriculture, Abeokuta, Nigeria in funding this project. We also acknowledge the significant contribution of Dr. M.O. Ozoje in reading through the manuscript.

\section{References}

Aina, A.B.J. 1992. Magnesium and copper requirement of young West Adrian Dwarf goats. Ph.D. Thesis of the University of Ibadan, Ibadan, Nigeria.

Aina, A.B.J. 2002. Effect of dietary salt levels on the performance of West African Dwarf goats. Nig. J. Anim. Prod. (1\& 2): 47-54.

Aina, A.B.J. and Abegunde, T.O. 2000. Investigating the effects of local potash ('Koun) on the performance of WAD goats. Book of Proceedings of $25^{\text {th }}$ Annual Conference, NSAP, Pg. 23.

Akinsoyinu, A.O. 1985. Nutrient requirement of sheep and goats in Nigeria. Proc. Nat. Conf. On Small Ruminant Production, Pg $141-146$.

A.O.A.C. 1990. Association of official Analytical Chemists, Official Methods of Analysis, Washington D.C.

Bondi, A.A. 1987. Animal Nutrition. English Edition, Published by John Wiley and Sons, N.Y.

Church,D.C. and Pond, W.G. 1988. Basic Anima Nutrition and Feeding. Printed by Schultz/Wach/Weir, 124 N.W. $9^{\text {th }}$ Avenue Portland, Oregon, 97209.

Davidson, N., Trevitt, L. and Parry, E.H.O. 1974. Peripartum cardiac failure: An Explanation of the observed geographical distribution in Nigeria. Bull. World Health Organisation Sc. $203-208$.

Duncan, D.B. 1955. Multiple Range Multiple FTests. Biometrics 9:1-42. 
Fontenot, J.P., Miller, R.W., Whitehair, C.K. and Macvicar, $R$. 1960. The effect of highprotein high-k ration on the mineral metabolism of lambs. J. Anim. Sci. 19:127 -131 .

Fontenot, J.P., Webb, K.E and Wise, M.B. 1973. Inter-relationship of $\mathrm{K}, \mathrm{N}$ and $\mathrm{Mg}$ in ruminants. Fed Proc. 32: 1925 - 1928.

Frandson, R.A. 1986. Blood and other fluids. In: Anatomy and Physiology of Farm Animals. Lea and Febige. Philadephia $4^{\text {th }}$ edition, $\mathrm{Pg} 233$ - 254 .

French, M.H 1957. Nutritional value of tropical grasses and fodders. Herb. Abstract. 27:1 9.

Gbodi, T.A. 1981. Possible model of preparation source of local salt licks (Kanwa and Kentu) and their chemical compositions as compared with commercial salt lick. Nig. J. Anima. Prod. 8 (1\& 2):23.

Gbodi, T.A. and lkwuegbu, O.o. 1982. Chemical composition of native mineral licks. Nig. Vet. J. 2(2):82-89.

Hafez, E.S.E. and Dyer, LA. 1969. Mineral Requirements. In:Animal Growth and Nutrition. Published by Lea and Febiger. Philadephia,Pg 312-331.

Heath, E and Olusanya, S. 1988. Haematology. In: Anataomy and Physiology of Tropical Livestock. ELBS edition, produced by Longman Sinagpore, Publishers Pte Ltd., Pg 30-33.

Idowu, A.O. 1994. A comparative study of the effect of 'kaun'(local salt) and 'Okan' leaf. B.Sc. Project, University of Agriculture, Abeokuta.
ITA, 1978. International Institute of Tropical Agriculture Manual Series. $1,2^{\text {nd }}$ Edition, pg 16-17,37.

Ivery, R.S., Luoma, L, Liesman, J., Thomas, J.W., Tucker, H.A. and Chapin, T.L. 1986. Effect of serum magnesium and feed intake on serum growth hormone concentrations. J.Dairy Sci. 69:1148 1150.

Kemp, A. 1983. The effect of fertilizer treatment of grassland on the biological availability of $\mathrm{Mg}$ to ruminants. In: Role of $\mathrm{Mg}$ in Animal Nutrition, Pg $143-157$.

Lufadeju, E.A. and Lamidi, S.O. 1993. Utilization of browse, grass, crop residues and other locally available agro byproducts as feed for ruminants. In: Advanced Animal Husbandry Practices for subject master specialists in ADP's Training Manual, $\mathrm{Pg} 75-83$.

McDowell, L.R. 1996. Feeding minerals to cattle on pasture. Anim. Feed Sci. Tech. 60:247-271.

Mahan, D.C. 1990. Mineral nutrition of sow: A Review. J. Anim. Sci. 68: 573- 583.

McDowell, L.R., Conrad, J.H., Ellis, G.L. and Loosli, J.K. 1984. Mineral for grazing ruminants in tropical regions. In: Book of Proceedings of $25^{\text {th }}$ Annual Conference, NSAP, Pg $81-85$.

NRC, 1988. National Research Council. Tables of feed composition and animal nutrient requirements. Appendix Tables 16 - 18; pg $413-418$.

Okagbare, G.O. and Akinsoyinu, A.O. 1998. Comparative utilization of sewage sludge, poultry droppings and groundnut cake rations by West African Dwarf goats. Nig. J. Anim. Prod. 25(1):58-62. 
Payne, W.J.A. 1990. An introduction to Animal Husbandry in the tropics $4^{\text {th }}$ ed. Tropical Agriculture Series, Pg 91.

Ranjhan, S.K. 1980. Mineral Nutrition and Metabolism. In: Animal Nutrition in Tropics. Pg. $106-130$.

RMRDC, 1996. Raw materials Research and Development Centre. Priority Investment Project in the solid minerals sector. Published RMRDC Abuja, Pg 81 - 87.

Schalm, O.W., Jain, N.C. and Carroll, E.J. 1975. Veterinary Haematology. $3^{\text {rd }}$ Edition, ICA and Febiger, Philadelphia, PP. 115 218.

Underwood, E.J. 1981. The Mineral Nutrition of Livestock. $2^{\text {nd }}$ Edition. Published by $\mathrm{CAB}$, Slough.
Uzegara, S.G., Morton, I.D. and Daniel, J.W. 1988. Quality changes and mineral content of cowpea (Vigna unquiculata L. Walp) seeds processed with 'kanwa' alkaline salt. Food Chem. 30: 1-18.

Vanfourtert, M.F.J. and Leng, R.A. 1991 . A note on the effects of high level of dietary $\mathrm{Ca}, \mathrm{P}$, and $\mathrm{Na}$ on nutrient utilization by sheep offered a roughage-based diet. Int. J. Fundamental and Applied Res. In: Book of Proceedings of $25^{\text {th }}$ Animal Conf. NSAP, Pg 23.

Wahua, T.A.T. 1999. Applied Statistics for Scientific Studies. Published by AfricaLink Books, Pg 129 - 137.

Received 10 July 2002; Accepted 27 September 2003). 